Article

\title{
Divine Light and Melodies Lead the Way: The Santmat Tradition of Bihar
}

\author{
Veena R. Howard
}

Department of Philosophy, California State University, Fresno, CA 93740, USA; vehoward@csufresno.edu

Received: 22 February 2019; Accepted: 20 March 2019; Published: 27 March 2019

\begin{abstract}
This paper focuses on the branch of Santmat (thus far, unstudied by scholars of Indian religions), prevalent in the rural areas of Bihar, India. Santmat—literally meaning "the Path of Sants" or "Point of View of the Sants" - of Bihar represents a unique synthesis of the elements of the Vedic traditions, rural Hindu practices, and esoteric experiences, as recorded in the poetry of the medieval Sant Tradition. I characterize this tradition as "Santmat of Bihar" to differentiate it from the other branches of Santmat. The tradition has spread to all parts of India, but its highest concentration remains in Bihar. Maharishi Mehi, a twentieth-century Sant from Bihar State, identifies Santmat's goal as śānti. Maharishi Mehi defines Śānti as the state of deep stillness, equilibrium, and the unity with the Divine. He considers those individuals sants who are established in this state. The state of sublime peace is equally available to all human beings, irrespective of gender, religion, ethnicity, or status. However, it requires a systematic path. Drawing on the writings of the texts of Sanātana Dharma, teachings of the Sants and personal experiences, Maharishi Mehi lays out a systematic path that encompasses the moral observances and detailed esoteric experiences. He also provides an in-depth description of the esoteric practices of divine light (drști yoga) and sound (surat śabda yoga) in the inner meditation. After providing a brief overview of the history and distinctive features of Santmat of Bihar, this paper will focus on the specifics and unique interpretations of the four structural principles of the tradition: Guru (spiritual teacher), dhyān (inner path of mediation), satsang (spiritual discourses or congregating practitioners for meditation or study), and sadācār (moral conduct). Through a close analysis of textual sources, Sants' oral discourses that I translated, as well as insights from my participant-observant experiences, I will examine how the four elements reorient the practitioner from the mundane world to the sacred inner experience of śanti.
\end{abstract}

Keywords: Santmat; Sants; religious experience; divine light and sound; medieval Sant tradition; moral conduct; modern gurus; sānti; dhyān; guru

\section{Introduction}

Santmat-literally meaning "the Path of Sants," "Teachings of Sants," or "Views of the Sants," -is a spiritual movement, which historically began in the twelfth or thirteenth century on the Indian subcontinent ${ }^{1}$. Santmat of Bihar represents a unique synthesis of the elements of the Vedic traditions, rural Hindu practices, and esoteric experiences, as recorded in the poetry of the medieval Sant Tradition ${ }^{2}$. Maharishi Mehi, a twentieth-century Sant from Bihar State, identifies Santmat's goal

1 Even though sant and saint are often used interchangeably, they differ in meaning. The term "sant" etymologically relates to Sat (Truth, Divine reality). Thus, sants are those who have realized the Divine Truth in this life. The term "saint," derived from the Latin sanctus (sacred), is often used for those holy men and women who are canonized by the church for their piety and deep spirituality.

2 I designate this tradition as "Santmat of Bihar" to differentiate it from the other branches of Santmat. The tradition has spread to all parts of India, but its highest concentration remains in Bihar. I draw some ideas from my 2017 article, 
as śānti (stillness; the ultimate peace). In his words, "Stillness or steadiness is the essence of Śānti and those who have attained Śānti are sants ${ }^{3}$." Like other Sant traditions originated in the medieval times, Santmat of Bihar is egalitarian in its approach. Maharishi proclaims that this state of sublime peace (inner realization of the Truth) is equally available to all human beings, irrespective of gender, religion, ethnicity, or status; however, it requires a systematic path. Drawing on the writings of the texts of Sanātana Dharma, teachings of the Sants and personal experiences, Maharishi Mehi lays out a systematic path, and provides an in-depth description of the esoteric experiences of divine light and sound that are encountered on the inner journey during meditation.

After providing a brief a historical context and distinctive features of Santmat of Bihar, this paper will focus on the specifics of the four structural principles of the tradition: Guru (spiritual teacher), dhyān (inner path of mediation), satsang (spiritual discourses or congregating practitioners for meditation or study), and sadācār (moral conduct). Through a close analysis of textual sources, Sants' oral discourses that I translated, as well as insights from my participant-observant experiences, I will examine how the four elements reorient the minds of the practitioner away from the sensory desires to the sacred experience of śanti. In addition, the four-fold structure also helps engender a social environment that constrains exploitative conditions.

In addition to this examination of the Santmat tradition's four elements, I will explore how its monastic leaders integrate the inner path to śanti with societal reform, especially with respect to caste, gender, and class inequities ${ }^{4}$. This represents an alternative model to popular, contemporary guru-disciple traditions, which have recently allowed for situations of abuse ${ }^{5}$. As a participant-observer at various ashrams and events in Bihar, Uttarpradesh, Delhi, and Kolkata since the 1980s, I have witnessed how the present-day monastic leaders make the path of light and sound accessible to men and women of all walks of life, especially those from the marginalized classes. This analysis reveals how religious experiences through an inner journey are significant for personal śānti (peace, spiritual freedom; realization of the Divine) and is also valuable for bringing about social harmony.

\section{Historical Context}

The Santmat tradition can be traced to the twelfth or thirteenth century although it may be considerably older than that as lives of many prominent female and male sants can be traced back to the seventh and eighth century. Julius Lipner states:

Before the advent of modernity, there was an influential vernacular 'movement', or more properly, a swell that attacked the privileges and discriminations of caste 'from below', that is, from a popular base among ordinary people. This has been called Sant-Mat, the View of the Sants or poet-saints, who became prominent in a broad arc from east to west mostly in the central and northern regions of the subcontinent from about the late thirteenth century ${ }^{6}$.

Lipner traces the historical factors that contributed to the rise of these vernacular systems throughout Central and Northern India. Religious orthodoxy in the prevalent forms of Hinduism - built on caste, gender, and authoritative hierarchal systems—-faced fierce criticism from various vernacular Sant movements. Many sects within the Sant movement share certain characteristics

“The modern monastic Santmat movement of Bihar: building bridges between Sanātana Dharma and Sant-Mat." https: / / link.springer.com/article/10.1186/s40613-017-0058-8 (accessed on 1 February 2019).

3 Maharshi Mehi, Mokșa Darśan (Philosophy of Liberation), translated by Donald and Veena Howard (Maharshi 1998, p. 7). It is now available online: https://archive.org/details/PhilosophyOfLiberationAManualOfSantMatMysticism/page/n19 (accessed on 15 February 2019).

4 Bhagat (1976) and Bronkhorst (1998) provide great historical insights into the tradition of renouncer. Maharishi Mehi's Guru (Baba Devi Sahib) never donned ochre robs, but Maharshi Mehi by virtue of his experiences and ascetic status redefined Santmat and took it to the deep villages of Bihar and Nepal.

5 In her recent article, Amanda Lucia provides a probing analysis of the issues of charisma and logics of the Guru-disciple relationship that create situations leading to sexual abuse.

6 (Lipner 2010, p. 129). 
with each other, such as rejecting caste and gender-based hierarchy, using a vernacular medium of expression, highlighting the importance of a Guru, and emphasizing one's personal religious experience. Nevertheless, these traditions are by no means "homogeneous ${ }^{7 "}$. There is a great variety of belief with regard to philosophical thought and soteriological practices. Because of this variety, the followers of each Sant (e.g., Kabir, Dadu) have distinctly identified their sects as Kabir Panth, Dadu Panth, and more.

Since the eighteenth century, the term "Santmat" has come to signify the non-sectarian institutions in Northern India that reject religious dogma and advocate the importance of a living, true guru (sadguru) and the inner path of Divine light and sound ${ }^{8}$. Historically, many of these traditions in one way or another trace their lineage to the eighteenth or nineteenth century Sant Tulsi Shaib (1763-1843), who lived in Hatharas, Uttarpradesh. The writings of Sant Tulsi Sahib, as well as various medieval Sants, points to the path of Divine light and sound by which practitioners traverse various physical and subtle regions in an inner journey aimed at the realm of the Divine-ineffable and infinite.

Even though a variety of splinter groups have emerged, such as Rādhāsoamī, Eckankar, and Kripal Singh's Ruhani Satsang, scholars have noted that the Rādhāsoamī movement "boldly proclaims itself to be the manifestation of sant mat (the Sant tradition) ${ }^{9}$." Furthermore, while Rādhāsoamī and Eckankar have been recognized as a part of the Sant tradition in textbooks on new religious movements, Santmat of Bihar, which is a parallel tradition that traces back its lineage to Sant Tulsi Shabi of Hatharas, has escaped any scholarly attention ${ }^{10}$. The reason behind such oversight includes (1) a lack of writings available in English translation until recently, (2) a lack of contact with Western academia due to its remote locations in the rural areas of Bihar, and (3) a lack of interest from the Santmat leadership in travelling to foreign lands.

\section{Distinctive Characteristics}

The twentieth-century leader of the monastic Santmat, Maharishi Mehi (1885-1986), who was born in a small Bihar village and chose a monastic life in his youth, redefined Santmat in the modern period $^{11}$. Maharishi Mehi did intense sādhana (meditation) in the caves of Kuppaghat Bhagalpur, Bihar. After emerging from his intense meditation, he spent many years researching the history and accounts of inner experiences throughout spiritual texts of the Vedas and the writings of Sants to various religious texts. From his personal experiences and research, he concluded that Santmat was not affiliated with any particular religious sect and its path could be practiced by followers of any religion, any social strata, or any gender. Maharishi Mehi presented a distinctive, organized framework for Santmat that included the following:

(1) Uniquely defining Sant, Santmat, and the goal as śānti (absolute peace, unity with the Divine).

(2) Identifying Santmat as Vedic Dharma (Vedic thought without fanaticism and extremism) through new commentaries on the Hindu texts.

(3) Showing resonances among the inner spiritual path of Sants, the sages of the Upanisads, and the mystical teachings of all religions.

(4) Building the structure of monastic leadership to spread the path to the most marginalized masses, which is similar to the ministry of the Buddhist Sangha.

(5) Determining the qualifications of spiritual leaders on the basis of their own spiritual accomplishments not on the bequest but the blessings of the Guru.

\footnotetext{
(Ibid., p. 130).

(Partridge 2004, p. 190).

(Juergensmeyer 1987, p. 329).

Some Indian scholars have done work on this branch of Santmat including advising Ph.D. thesis on the various aspects of Santmat of Bihar.

11 Maharishi Mehi's Guru, Baba Devi Sahib, was born with the blessings of Sant Tulsi Sahib and said to have said to have received blessings from him as a child.
} 
The Rādhāsoamī tradition has set itself apart through its unique, single-lineage-based identity, which has continued for over 200 years. Santmat of Bihar has spread through monks who are initiated and blessed by the senior monks, but not necessarily are formally enshrined as the only leaders in the lineage. In fact, the tradition lacks a formal system of lineage of one single salvific figure, who holds high power ${ }^{12}$. Nevertheless, all monastic leaders consider Maharishi Mehi their model and yield to his spiritual power. They do not assert their own individual charisma or accomplishments, which creates a unique atmosphere for grassroots movements to spread the teachings of Santmat. Thus, the identity of the Santmat of Bihar is grounded not in a formal lineage, but in a unique spiritual vision captured by these features of Santmat of Bihar.

\section{Santmat Redefined}

Historically, the terms Sant and saint have been used interchangeably even though they connote distinct meanings. It is difficult to find a text that succinctly defines "Sant" and "Santmat." In his book Mokșa Darsana, Maharshi Mehi provides a detailed definition:

1. śānti is the state of inner tranquility and equanimity [absolute inner peace, unity with the Divine $]^{13}$.

2. Those recognize as Sants have experienced the inner śanti $i^{14}$.

3. Santmat encompasses the thoughts and way (mat) of Sants.

4. The desire to attain śānti is natural in human beings. Inspired by this inherent desire, seers of ancient times searched for the inner peace and found the path to attain it. This path has been expounded in the Upanisads ${ }^{15}$. Similar views have been expressed by more recent sants such as Guru Nanak and Kabir Sahab. They expressed their views in Punjabi and Hindi vernaculars, respectively ${ }^{16}$. Such expressions in native languages were meant to inspire and instruct the people of all backgrounds. The teachings of these later Sants are what is referred to as Santmat ${ }^{17}$.

A systematic elucidation of the Santmat's principles structures the theoretical foundation for the Santmat monastic movement. For Maharishi Mehi, "the Upanișads must be considered the foundation of Santmat because they uniquely and copiously elucidate on the means for attaining śānti ${ }^{18}$." Drawing on the later Upaniṣads, such as Nādabindopaniṣad, Śạndilyopanișad, Dhyānabindopanișad, and Yogaśikhopanișad, he argues that "the Upaniṣads explain the yogic techniques and systematic

12 Dimitrova (2007) demonstrates how one guru of Rādhāsoamī movement sought to appropriate the concept of Sanātana Dharma.

13 Śanti is a Sanskrit word with several English meanings such as "peace," "tranquility," "bliss," etc. The peace that results from some degree of Divine communion is śānti.

14 A sant in the Santat tradition is one who experiences Sat (Truth), the mystical state of divine union. It is a title conferred because of yogic achievements. A saint of the Santmat tradition is one who has achieved the realization of the Divine, and, subsequently, his behavior is moral. Clearly, many Western saints also fall into the Santmat definition of saint. The words "sant" and "saint" are used interchangeably.

15 Maharishi Mehi focuses on the select Upaniads in order to support this thesis. In his research on yoga and the nature of $\bar{a} t m a n$ and Brahman, he cites passages from the texts, including The Bhagavad-Gìtā and Śvetâśvatara Upanișad. For his support for the path of Divine Light and Sound, he draws on the later Upaniads, including from Nāda Bindu Upanișads, Dhyānabindu Upaniad, and Śäilyopaniad. He does not concern himself with the academic debates on the authority and authenticity of the earlier Upaniads.

16 The seers of the Upanișads wrote in the Sanskrit language, which is not a language of the common people. According to Maharishi Mehi, Guru Nanak and Kabir Sahib elucidate the same Upanișadic wisdom in vernacular, regional languages understood by common people.

17 Maharshi Mehi, Mokșa Darśan (Philosophy of Liberation), translated by Donald and Veena Howard (Maharshi 1998, p. 7). It is now available online: https:/ / archive.org/details/PhilosophyOfLiberationAManualOfSantMatMysticism/page/n19 (accessed on 15 February 2019).

18 Maharshi (1998, p. 8). https://archive.org/details/PhilosophyOfLiberationAManualOfSantMatMysticism/page/n19. 
views of transcending mind and attaining the Absolute through the path of Divine Sound (Yoga of Surat-Śabd $)^{19}$." This move was to create a bridge between the Vedic wisdom and Sant teachings.

Not only does Maharishi Mehi locate the path of Santmat in the Vedānta literature, but he also establishes the underlying unity among the teachings of the Sants, saying:

Often the teachings of various Sants would, on the surface, seem contradictory to each other or even contradictory to the principles of the Upanișads. However, there is an unbreakable unity in the spiritual path of all Sants and Sages. These variations are due to the fact that different times and in different regions Sants appear, and their followers name their tradition after the particular sant [and formulate the teachings in regional dialects] ${ }^{20}$.

According to Maharishi Mehi, the apparent differences among the Sant teachings can be attributed to the variation of regional languages and traditions. By virtue of his renunciate stature, Maharishi Mehi accepted the inner mystical truths elaborated in the texts of Sanātana Dharma while rejecting religious factionalism and extremism. Furthermore, through his careful commentaries, including Ved Darśan Yoga (the Philosophy of Vedas), Śri Gìtā Yoga Prakāś (the Light of Gītā Yoga), and Rāmcarit Mānas Sar Satīk (The Essence of Rāmcarit Mānas), he sought to render the essence of these texts consistent with the principles of Santmat ${ }^{21}$. Most importantly, Maharishi Mehi's insights are accessible to all since Santmat of Bihar is inclusive of the non-literate religious vernaculars.

He emphasized the harmony among all religions on the basis of his personal experiences of the divine light and celestial sounds that are found in the religious writings across traditions. While his argument and deductive reasoning can appear to be an effort to create some kind of uniformity among the teachings of various Sants, Maharishi Mehi invited his followers and opponents alike to experience this truth through which factionalism fades way. Simultaneously, he recognized the differences of external practices, but emphasized the shared experiences of divine light and sound. He also drew attention to the common beliefs of the necessity of a qualified master (Guru) and observing moral conduct for treading the inner path. This is the reason he preferred the inclusive term "Santmat," instead of adopting a specific name as Rādhāsoamī or Eckankar.

Since Maharishi Mehi's passing in 1986, many monks have continued to produce literature and impart the teachings of Santmat in various regions of India. Numerous accomplished monks who were initiated by Maharishi Mehi have spread the teachings to different regions of Bihar, West Bengal, Punjab, Jammu \& Kashmir, Gujarat, Nepal, and Uttarpradesh. Maharishi Mehi travelled to these regions and currently other monks spread the teachings of Sanmat in different areas. I have visited at least five different regions where Santmat's leaders have established ashrams to continue the teaching of Santmat. Despite various subgroups within Santmat of Bihar, they are consistent in abiding by the four essential principles of Santmat, as developed by Maharishi Mehi for progressing on the path to śānti.

\section{The Four Principles: A Structure for Supporting the Path to Śanti}

Maharishi Mehi maintained that all humans, irrespective of their religion, gender, class, or caste, can traverse the path of inner spiritual regions and attain śanti, which is a declaration that was made after he deeply studied sacred texts from different traditions and had his personal inner journey to the inner realms. Similar to the compositions of Kabir and Nanak, he documents his experiences in his poetry. He systematically organized Santmat's philosophy and path in numerous texts and voluminous

19 Surat Śabda (the Yoga of Divine Sound) is the practice of transcending the mind and entering the level beyond the mind, the level of Oneness. The vehicle for this inward journey is Sound. The way to employ Sound and to understand its use is the practical application of Surat Śabda Yoga. This is also known as Nādānusandāna (lit., "search of the divine sound").

20 (Maharshi 1998, pp. 7-8). For example, even though Sant Kabir was non-sectarian, his tradition is named as Kabir Panth and Guru Nanak's teachings eventually led to the formation of Sikh Dharma (Sikhism).

21 In his article, "The Bridge between Hindu Scriptures and Santmat," Pravesh Singh demonstrates how Maharishi Mehi builds bridge between Hindu scriptures and Santmat (Singh 2013). 
transcribed lectures. In the last 14 years, I have translated three books of different Santmat Gurus, but most of the texts and oral teachings recorded in the monthly periodicals remain untranslated. By analyzing the translated texts and oral teachings, I will examine each of the four elements that serves as scaffolding for ascending the inner path to the Divine: guru, dhyān, satsang, and sadācār ${ }^{22}$.

Santmat of Bihar shares some of the elements with the Rādhāsoamī and other Sant traditions, but provides a unique interpretation of each. For example, in explaining the importance of the spiritual guru, Maharishi Mehi quotes various Hindu texts and synthesizes Sant and Vedic wisdom. Instead of rejecting the scriptures of Sanātana Dharma, Santmat's leadership of sannyāsiss show that all of these principles exist in the texts of Vedic Dharma, including the Upanisads, Rāmāyana, and the Bhagavad-Gìtā. Furthermore, Santmat of Bihar uses vernacular language to make these principles accessible to people who are steeped in the myths of Hindu religiosity. I show how these principles are reconstructed to include the tribal and people from the rural areas of Bihar, Uttarpradesh, and Nepal, which are areas that culturally and religiously relate to vernacular Hindu religiosities.

\subsection{Guru}

All branches of Santmat recognize the necessity of a living guru (literally "dispeller of ignorance") and many subgroups continue the tradition of transferring the guru's legacy to their disciple. Scholars ${ }^{23}$ have analyzed historical, religious, and social reasons for the consolidation of the guru's power from the medieval period to contemporary times. The tradition of the guru-disciple can be traced back to the instances of such a relationship in the Upanișads, the Ramāyāna, and the Mahäbhärata. In the Bhagavad-Gitta, Lord Kṛsṣna does not use the word "guru," but alludes to the giver of knowledge.

Learn the truth through humble submission, through inquiry, and through service. The wise one, who has realized the truth, will impart the knowledge unto you (4:34).

Many references in the Upaniṣads liken an enlightened Guru to Brahmā, Viṣnnu, and Śiva. Upanișads, Tantras, Pūrānna, and the writings of Sant traditions emphasize the importance of a realized Guru on the inner path.

Most writings of Sant traditions do not cite Vedic or Hindu texts on the importance of Guru. They only refer to the writings of the medieval gurus like Kabir, Palatu, and Dadu. The tradition of Guru-disciple relationship continues to this day. Most Hindus look to blessings and guidance from holy men and women. In her recent article, Amanda Lucia analyzes the conditions that spawn abusive actions by modern gurus. She lays out the historical facts surrounding guru worship in the Indian context: "Devotion to living persons who are believed to have special wisdom and power has existed in India since antiquity ${ }^{24}$." Drawing on her ethnographic experiences, she provides a probing analysis of the "structural aspects" (including devotees' longing for proximity to their guru) of sexual abuse by "headline stealing hyper-gurus." Furthermore, she investigates how devotees' desire to experience the gurus' charisma and radiance and "the authoritarian power relationship between guru and disciple create social situations that are readied forums for sexual abuse ${ }^{25}$."

Notwithstanding the scintillating stories of the modern gurus, Santmat has embraced the tradition of a sanctified guru-disciple relationship. However, it makes a clear distinction between the outer power (charisma) and the inner power (experience of light and sound). Likewise, the writings of Santmat emphasize the nirguna (attribute-less) form of the Divine but does not reject saguna bhakti (visualization on the form of $g u r u$ ) to reach the nirguna. The inner, radiant form of the guru is the

\footnotetext{
22 In his research on the modern Rādhāsoamī movement, Mark Juergensmeyer (1987) shows its connections between the teachings of Sants like Kabir, Dadu, and Nanak, but, at the same time, he calls attention to its unique elements, including "the inner path of spirituality," "necessity of Guru," and "the fellowship of Satsang." See Juergensmeyer (1987, pp. 329-55).

23 For example, Gold (1987); Juergensmeyer (1987); and Lucia (2018).

24 (Lucia 2018, p. 956).

25 (Ibid., 953).
} 
focus of meditation. My observations and conversations with the gurus in the Santmat of Bihar reveal that the tradition cautions against conditions that might prompt physical or emotional abuse, while emphasizing the necessity of an accomplished guide on the inner path.

Maharishi Santsevi, a close disciple of Maharishi Mehi, writes:

The spiritual teacher gives knowledge of the Self, reveals the true form of the Divine, and, thus, brings blessing into our lives. Therefore, the seeker of spiritual knowledge must ... seek a true spiritual guru ${ }^{26}$.

By emphasizing that a true guru is not merely a human body, Maharishi Mehi preempts any attachment to the bodily charisma of the guru. He also differentiates between qualified and unqualified gurus when he quotes Sant Kabir: "The Guru is a manifestation of wisdom, and an aspirant should acquire this knowledge. Without the understanding of true knowledge and moral principles, there is neither a guru nor the true seeker ${ }^{27}$." Many Sants, including Tulsidas, Guru Nanak Dev, and Kabir sing praises of the Satguru who has experienced the Truth (sat). Maharishi Santsevi, who is an esteemed teacher of Santmat, quotes Saint Sundar Das who sees the guru as the purifier of worldly entanglements.

By the grace of the Guru, our intelligence is refined and purified, and by the grace of the Guru, the sorrows of this world are removed.

By the creation of God, the soul descends [into the web of this world]. However, by the teachings of the Guru, the same soul is liberated from the net of illusion and death (Yama) ${ }^{28}$.

Santmat emphasizes that seekers must reject those spiritual leaders who lack stringent moral disciplines and warns against those gurus who mislead the practitioners by generating illusory experiences of light and sound through external means. A Guru must be a realized human being who is able to guide the followers on the inner path of light and sound. Swami Vyasanand provides examples below.

Some even use computer generated images of various colors and stars in order to experience the Divine light. Some play music in order to focus on the Divine sound ... These kinds of practices and experiences are illusory, taught by misguided gurus who themselves do not know the inner path of light and sound ... Consequently, the seekers face obstacles on the path of Truth ${ }^{29}$.

Moreover, a true Guru is compassionate and dedicated to the well-being of the society and rejects social evils that are sources of communal strife and personal anguish.

Monastic and lay followers of Santmat of Bihar consider Maharishi Mehi as a role model for the devotees. After returning from deep states of meditation in the 1930s, Maharishi Mehi dedicated himself to teaching the most marginalized groups in Bihar and sought to confront caste-based oppression and gender discrimination. He proclaimed that all human beings can tread the path of light and sound, and he threw open the gates of esoteric and guarded teachings to all by initiating hundreds of people in one sitting. The Guru's role is not simply a conduit to initiate the seeker into the path of śānti, which Sants have often emphasized. It was also to bring outer śānti (peace), social harmony. Maharishi Mehi, however, cautioned against only doing works of social service without a diligent focus on the inner path.

\footnotetext{
(Maharishi 2008, p. 322).

(Ibid., pp. 322-23).

Ibid., p. 327)

(Swami Vyasanand 2016).
} 


\subsection{Dhyān (Meditation)}

Santmat offers a systematic path to self-realization and absolute inner peace through dhyanna (meditation). The specifics of the path and the markers of experiences of the Divine light are provided in detail, which begins with ekāgr dhyān (one-pointed focus). The path is consistent with the Yoga practice as elaborated by Patañjali, who emphasizes the practice of $e k \bar{a} g r a t \bar{a}$ (concentration) for controlling the mind as "Yoga practice begins with ekāgratā, which dams the mental stream ${ }^{30}$." Santmat Gurus initiate the seekers into precise methods to cultivate one-pointed concentration to experience inner Divine light and sound. Santmat's path of yoga begins with efforts in concentration and culminates in deep focus.

According to the teachings of Sants, the inner path cannot be realized through the nine gates of the body (i.e., through the sensory organs) but only through the tenth gate (i.e., the third eye or the spiritual eye). The actual journey requires a broader and more detailed instruction in the stages of meditative experiences. Maharishi Mehi says: "Three covers of darkness, light, and sound encumber the soul. We need to lift this veil to have the vision of the Divine ${ }^{31}$." Thus, Santmat is often referred to as the path of Divine light and sound because both of these phenomenal elements serve as landmarks of inner experiences that culminate in the realization of the ultimate peace and union with the divine.

Swami Vyasanand who is one of the contemporary teachers of Santmat elaborates on the process of religious experiences of light and sound encountered by the practitioner.

Initially, when practitioners close their eyes, the darkness is seen within. Then, after some time of diligent meditation practice, the light emerges. At that time, the practitioner experiences light that is similar to the sparks of light emerging from the rubbing of two stones. When the practitioner begins to focus for longer periods, then he experiences the light similar to that of lightning flashes amid the dark rain clouds. Then, the vision will be concentrated on this light bindu. At this juncture, the gaze through the power of increased concentration will transform into a very fine needle-like point. In addition, through the light bindu (the tenth gate), the practitioner enters into the realm of light. The experience of divine light in the meditation brings joy, and the progress then becomes rapid. Consequently, one's faith and conviction become stronger ${ }^{32}$.

When a spiritual seeker sits in meditation, he/she makes an ascending journey, rising from the $\bar{A} j \tilde{n} \bar{a}$ Cakra (variously termed as the divine gate, third eye, divya cakṣu, tīsrā til, dasham dwār, śiv netra, trinetra, etc.) into the region of the thousand-petalled lotus, or the Sahasrāra. Maharshi Raman calls the third eye "the Agni Cakra." This is the place where the channels of Id̄a and Pingala converge. In this case, the subtle light-point begins to emerge. Ascending further, when entry is made into the Trikuti the inner Sun becomes visible by seeing that the seeker acquires the supernatural or the divine vision in order to be able to see all the three worlds. Maharishi Santsevi uniquely shows a path of light and sound in the Upanisads. He quotes Yogashikhopanisad (6.6).

The $\bar{i} d \bar{a} n \bar{a} d i$ is on the left and pingla nādi is on the right. One who focuses at the center of these two [on the susmna] is the true knower of the Vedas [divine knowledge] ${ }^{33}$.

The teachers of Santmat show resonance between the Dhyāna practice of focusing on the suṣmna and the concentration on the third eye (tīsra $t i l)$, as elaborated by various Sants. The experience of Divine light leads to the divine sound or melody, which, in turn, leads to the state beyond any sound and form, which is the formless state of Truth. Various Sants elaborate on the alluring nature of the

\footnotetext{
(Eliade 2009, p. 48).

(Swami Vyasanand 2016).

(Ibid., 2016).

(Maharishi 2008, p. 344).
} 
divine melodies. In Sant Kabir's words, "The five kinds of sounds reverberate within, and thirty-six kind of divine melodies are also found within ${ }^{34}$." When the practitioner experiences various aspects of the light realm, consciousness initially is not drawn toward the divine sound due to its attraction to the light. In the higher light realms, the bright light of the sun destroys the residue of impurities of the mind. Purity (sattva) pervades the consciousness and rajas completely vanishes.

It is, at this time, that the scenes of the light realm that form the reality of name and form begin to fade, and merge into the formless. The divine melody of the formless realm becomes increasingly powerful, to the degree that, even though the experience of divine light subsists, the consciousness current (surat) does not become distracted. Similar accounts are given by both medieval and modern Sants, including in the Rādhāsoamī Sant tradition. Mark Juergensmeyer writes: "In the theology of the movement, the eternal essence of God resides in the form of pure energy: light and sound of matchless and incredible purity ${ }^{35}$." Admittedly, there are resonances among Rādhāsoamī writings and the teachings of the Santmat of Bihar, but Maharishi Mehi uniquely organized the stages of the path and provided markers for the inward journey, which he also illustrated in a chart of the inner region ${ }^{36}$.

Over the last two decades, I have observed that this esoteric path, despite its subtleties, is not imparted only to a select few, nor are the experiences of light and sound limited to monastics. The modern monks impart the teaching to all people, male and female, irrespective of their status and caste, who seek guidance, especially to those in rural areas of Bihar. Furthermore, the gurus of the tradition hold week-long or month-long meditation retreats where hundreds of practitioners gather to meditate five times a day for one-hour sessions, beginning at three in the morning ${ }^{37}$. At one recent retreat in Prayag at the Kumbh Mela, along with the daily meditations, the Guru mantra was recited twenty-four hours each day for one month. The devotees took turns in unceasingly reciting the mantra out-loud. Such ceaseless chanting is the ritual of continuous chanting of Siva mantra or reading of the Rāmāyana. These retreats place great emphasis on inner experiences and such a regimented, intensive schedule helps the practitioner to tread the path of Divine light and sound.

The practitioners are instructed to disclose their experiences only with the Guru and seek further guidance on the path. In the exuberance of joy, however, some devotees share their experiences with other devotees. One female informant attended a week's long meditation retreat in a Bihar. She told me in 2005 that she sat in meditation each day for several hours. Her concentration deepened and she began to see flashes of light with beautiful colors. As she continued, her experiences generated great joy and bliss. She shared her experience with the Guru who affirmed the validity of her experiences. She was so entranced by these experiences that she desired longer time in meditation, which was unusual for her. Even after returning home from the retreat, she continued to experience the light while in meditation and feelings of joyfulness in her daily activities. The reports of such experiences generate enthusiasm in the hearts of seekers when they relate them to others. Such reports indicate that dhyān yields the results promised by the initiation into the path of light and sound. To make progress on the path, Santmat underscores the company of other truth-seekers, known as satsang.

\subsection{Satsaing}

Satsang is an essential component of all branches of Santmat. The term satsang is the compound of two words: sat and sang, meaning "association with the Truth" or "association with the Sants" (who have realized the ultimate Truth). Although the term satsang is used generically for a sacred gathering,

\footnotetext{
34 Sant Kabir variously speaks about the divine melodies: "The five-sounded melody keeps reverberating and my soul is ever attracted by It as a Sarang is ever after water." O the Formless One beyond all knowledge! I worship thee with all my heart." https: / / www.ruhanisatsangusa.org/naam/naam_shabd5.htm (accessed on 1 February 2019).

35 (Juergensmeyer 1987, p. 339).

36 https://www.speakingtree.in/blog/inner-cosmic-chart-as-sketched-by-maharshi-mehi-paramhans (accessed on 15 February 2019).

37 The practitioners come from different regions. This is evident from the language they speak, which include Hindi, Bihari, Nepali, Avadhi, Nepalese, Bengali, Marwari, Gharvali, and many others. Usually teachers give discourses in Hindi or Bihari.
} 
Maharishi Mehi uniquely stratifies it into the two categories of inner and outer. First, the inner satsang refers to association or coming into contact with Sat (truth) or the divine. This is the highest form of satsang, and it connotes the deep state of meditation in which consciousness unites with the divine. It is a state beyond senses because only the soul or consciousness is capable of merging with the divine. "True satsaing is the unity of the soul with the Supreme Truth ${ }^{38}$." However, this highest kind of satsang, unity with the Divine, does not occur suddenly. It requires many lifetimes of good actions resulting in good samskāras (spiritual imprints and tendencies). The second kind of satsang signifies "association with the Sants or truth seekers." Various medieval Sants elucidate this further. For example, Sant Tulsidas Ji emphasizes the association with the saints in realizing the divine: "The association of the saints brings association with the divine, and alliance with people who are engrossed in the world leads the way back to this world again and again ${ }^{39} . "$

The monastics and lay followers participate in weekly and annual gatherings of followers. I provide a glimpse of the nature of satsang through my own experience in Bhagalpur, Bihar. The guru, who is a monk in ochre robes, sat on a stage with other sādhus, and gave the audience (darśan) to the followers who sat on the ground. Most followers, who were illiterate, came by foot, bullock-carts, bicycles, or any other vehicles from the nearby rural areas. The gathering consisted of monks and lay men and women of various strata of Hindu society, from both urban and rural areas. The discourse primarily focused on the importance of the right conduct for the inner esoteric path of meditation. They were strewn with stories from the Rāmāyana and the medieval and contemporary Sants' lives. I was told that the tribal and rural people, who were initiated into the teachings of Santmat, used to perform animal sacrifices and consume intoxicating substances. But now, having been initiated into Santmat, they have become vegetarian and have stopped the tribal traditions of sacrifice and consumption of alcohol, and bidis (homemade cigarettes). In a recent (14 March 2019) OPED piece, Promod Mishra shares his encounters with a senior monk of Santmat in Nepal. He highlights the egalitarian and inclusive nature of satsang of Santmat of Bihar ${ }^{40}$. Although the monks have chosen to live separately from society by virtue of his monastic lifestyle, they travel from village to village to offer teachings and guidance to all who wish to study and learn. Santmat of Bihar does not ask its followers to stop their own Hindu, Sikh, or other rural religiosities, but, instead, teaches the incorporation of Santmat's teachings in the daily lifestyle.

Most rural devotees do not even speak Hindi, only regional languages. They sing bhajans (sacred songs) in Hindi and regional dialects. Most Indian religious ceremonies often include the ritual of $\bar{a} r t \bar{\imath}$ by lighting lamps and burning incense. Santmat of Bihar's a $r$ rti does not incorporate the more typical $p \bar{u} j \bar{a}$ paraphernalia of lamp and incense, but, rather, is a devotional song in which the symbolic offering of the $p \bar{u} j \bar{a}$ is recited together to culminate a satsang. Symbolic representation of the ritual satisfies the tradition of ceremonious performance. At the same time, it invites the followers to remember the inner spiritual states represented by the outer ritual. The devotees of Santmat, many of whom come from rural areas and have no formal education, have memorized the $\bar{a} r t \bar{\imath}$ and sing it every morning and evening as a part of the daily worship.

Perform ārtī in the body-temple I

Be still and the two rays of sight to meet in the mid-eyebrows | | 1 | |

An immensely illuminated point shines there I

Behold the Divine Light incomparable | 2 |

Many celestial planes flash within I

Behold and then move ahead || 3||

\footnotetext{
(Maharishi 2008, pp. 322-23).

Ibid., p. 317.

40 Mishra, Pramod. “Practice What You Preach.” Kathamandu Post, March 14, 2019. http:/ / kathmandupost.ekantipur.com/ news/2019-03-14/practice-what-you-preach.html (accessed on 18 March 2019).
} 
More simple is the Yoga of Inner Sound I

Practice it to clasp the Divine Sound | $|4|$ |

Such technique takes beyond the fort of bodies I

Destroys worldly illusion and maladies | |5 | |

This sublime ārtī shatters the delusions of duality I

Perform, O Mehi, and drink the elixir of immortality || 6||$^{41}$

The public chanting of $\bar{r} r t \bar{t}$ summons the devotees to tread the path of the divine light and sound, but they are asked to keep secret their individual inner experiences. This ritual practice occurs both in morning and evening in each āśram founded on the philosophy of Maharishi Mehi. In this practice, the Hindu religious sensibilities are transformed into esoteric experience through the recitation. Maharishi Mehi also composed a compendium of verses Padavali-a litany of supplications, warnings, and inner experiences-which are evocative of medieval sant poetry. Men and women sing these verses in melodious tunes during communal satsaing and in their daily practice. In the current age of social media, many young male and female followers use the digital media to share their recordings of these songs (bhajans).

Daily and weekly satsangs are held in the local ashrams or in the followers' homes. I was told by one of the current leaders that there are about 1000 ashrams of Santmat of Bihar all over India, primarily in rural areas. Both monks and laity of all castes, genders, and social status equally participate in satsanig and dhyān. The sādhu's monastic lifestyle and the locale of the ashram community form "communitas" to use Turner's (1995) language, which transcends the socially imposed structures of caste and gender. Turner says,

This comradeship transcends distinctions of race, age, kinship position, and, in some kinds of cultic group, even of $\operatorname{sex}^{42}$.

Furthermore, Santmat's monastic leaders negotiate the customs of Hinduism by providing esoteric interpretations of rituals and customs. This helps them guide the followers to the highest state of truth, while simultaneously defying the deceptive social fragmentations of caste and gender inequities. The tradition also seeks to strengthen the moral backbone of the seekers and society through precise instructions of ethical conduct.

\subsection{Sad̄̄ā̄r}

Sadācār, which means "moral conduct," is considered essential to the journey on the path of light and sound. The gurus of Santmat give specific instruction on conduct for embarking on the inner path $^{43}$. Despite some variations, the five restraints prescribed by Santmat broadly correspond to the five Yamas (Yogic restraints) and Pañc Śîla (Five Ethical precepts) of Buddhism, which are oriented to purify the seekers' conduct and prepare them for the path ${ }^{44}$. The monastic leaders of Santmat of Bihar draw on the teachings of various Sants who deem moral conduct as a necessary precondition for the inward path. Guru Nanak Dev Maharaj stresses the need for purifying the body and mind: "It is only in a pure, clean vessel that truth can stay. Those who lead a pure (moral) life are rare. I seek refuge in God: Lord, merge my essence into your Supreme Essence ${ }^{45 ! "}$

41 Maharishi Mehi, Maharishi Mehi Padavali (Verses of Maharishi Mehi). Translation is my own. Maharshi Mehi Padavali's translation has not been published. The verses are written in Bihari vernacular, but they also include words from Hindi and Sanskrit.

42 Turner (1995, p. 100).

43 The initiates are asked to abstain from five vices: lying, stealing, use of intoxicating substance, violence, and sexual misconduct. The practitioner also takes the vow of observing vegetarian lifestyle.

44 The five prohibitions are similar to those in the Yoga, Buddhist, and Jain traditions. There are some differences in all three. For example, Yogic and Jain vow to avoid greed and Buddhist disciplines and will abstain from intoxication. Often abstaining from killing also includes not consuming an animal diet.

45 (Maharishi 2008, p. 329). 
In his lectures, Maharishi Santsevi compared an immoral mind and body to a heap of dirt or waste and advised mental and physical self-control. He quotes the Katha Upanișad below.

The one who has not abstained from sinful acts, whose senses are not in control, and whose mind is not serene cannot attain the Supreme Reality by the practice of self-realization ${ }^{46}$.

With these views in mind, Maharishi Mehi as a renouncer, incorporated morality into the initiation by creating a mandate for five vows: abstaining from lying, stealing, intoxication, violence, and adultery. Louis Dumont observes that in Indian religion renouncer has been a "creator of values ${ }^{47}$." Maharishi Mehi argued for the value of moral vows in religious, social, and political contexts. The initiated individuals who commit to these prohibitions report transformation in their personal and social lives. Maharishi Mehi once proclaimed: "If we are able to rid ourselves of these five sins, then how could other sins trouble us?" It implies that these five vows protect the seekers from various immoral actions.

Santmat of Bihar includes a vegetarian lifestyle as part of abstaining from violence. In Maharishi Santsevi's words,

The saints have addressed the sin of violence with particular attention to the foods that are eaten. Foods produced by killing living beings, as well as foods that are not pure and fresh, are considered tamasic (causing inertia). Consumption of these types of foods is prohibited by the teachings of the saints ${ }^{48}$.

Animal products such as meat, fish, and eggs are said to inhibit the clarity of the mind and the health of the body. There is an old saying: "Whatever kind of food we take in, its properties will also fill our mind ${ }^{49}$." Through my conversations with the devotees, I learned that the seekers are asked to follow a vegetarian diet and abstain from any intoxicating substances for at least six months before their initiation into the path of light and sound. Such restrictions ensure the seeker's commitment to the ethical lifestyle prerequisite for the inward journey.

A firm emphasis on morality and rules to circumscribe physical contact between the monastic and the lay community also obviate the possibility of corruption. Such restrictions prevent immoral conduct and scandalous episodes that make the headlines. Maharishi Mehi not only gave precise instructions for moral conduct, but he also provided stringent restrictions on the display of supernatural powers. He affirmed that the progress on the inward path also yields supernatural powers to the practitioner. Many hagiographic accounts of medieval Sants and the Sants of Rādhāsoamī also attest to such accomplishments. However, Maharishi Mehi warned against any display or misuse of religious experience or accomplishments. He prohibited any display of siddhis (supernatural powers) and prescribed even more strict rules for the monks, including avoiding any personal contact with the followers for imparting śakti and paying close attention to all five vows. In one of his talks, Maharishi Mehi related his conversation with a newcomer who asked whether he had the power to make miracles. He responded with great serenity: "In our tradition, we make the miracle of morality." Scholars and supporters alike bemoan the fact that many gurus boast miracles, but lack morality, which is a crucial component to tread the spiritual path. Sanmat of Bihar addresses the issues of social reform by integrating it with personal spiritual progress.

\section{Santmat: Linking Personal Spiritual Development with Social Reform}

The monastic movement Santmat of Bihar uniquely connects inner Śānti with outer peace and harmony. Many Santmat monks travel to rural and tribal areas of Bihar, Uttarpradesh, and Nepal to 
teach the inner path to the people who lack adequate means to travel. Many of these communities have traditionally been immersed in orthodox customs of caste-based purity laws, gender biases, and even the performance of animal sacrifices due to the fear of deities. Many followers report the transformation after being initiated by the gurus. The renouncer gurus address both the spiritual and social well-being of their followers. The renunciate Santmat leaders' active involvement with social reform differs from the lifestyle of traditional renouncers of India's religious traditions ${ }^{50}$. In India's pre-colonial past, although the renouncer was viewed as the catalyst for the progression of new ideas, conventionally a mahātm $\bar{a}$ or sādhu was typically identified by his renunciation of worldly ties in the pursuit of ultimate freedom (mokșa). This is the predominant vision of renouncers endorsed by many colonial writings and, to a large extent, featured in Brahmanical textual models of sannyāsa (cf. DeNapoli 2014a, 2014b). However, renouncer-monastics like Maharishi Mehi, and those within his lineage, challenge this simplistic and detached view of sannyāsa, which is consistent with the twentieth-century model of engaged spirituality.

During the twentieth century (in which Maharishi Mehi assumed leadership of Santmat), religious and Indian religious and social reformers, including Swami Vivekananda and Mahatma Gandhi, disapproved of the world-denying philosophy (nivrtti), so visibly represented by sādhus and sannyāsiss, for India's colonization. As John Campbell Oman has argued: "It is largely due to the subtle effects of the spirit of sadhuism upon the character of the people of India that the country is so easily governed by a handful of foreign officials and a few thousand white soldiers ${ }^{51}$." The outsiders' colonial dominance and critiques of Indian culture and religious life engendered critical discourse among elite native Indians "toward their own traditions ${ }^{52}$." Eventually, according to Kirin Narayan, he indigenous response to foreign criticism during the colonial era led to a reinterpretation of the value of renunciation and a revolution in the role of the sādhus, which "usher[ed] in the image of the socially involved renouncer ${ }^{53}$." Swami Vivekananada proclaimed, "Love and charity for the whole human race, that's the test of true religiousness ${ }^{54}$." Maharishi Mehi was moved by the suffering of the rural people, especially from lower social and economic strata, who did not have access to any spiritual path. Throughout this life, he travelled to the deep villages to deliver the path of light and sound to the common people.

Mahatma Gandhi, contemporary of Maharishi Mehi, appealed to sādhus to become more engaged in society. Although uniquely monastic, the concern for the total well-being of the followers is the hallmark of Santmat. Therefore, Maharshi Mehi emphasized self-supporting (living by one's own earning), socially concerned industrious followers. By virtue of its unique monastic leadership, Santmat of Bihar negotiates both the acceptance of select ideologies of the Vedic Dharma and the rejection of religious factionalism and extremism. Most importantly, it includes the non-literate religious vernaculars. Additionally, it openly accepts all, regardless of caste, creed, sex, or even nationality. Notably, despite large female followers, only male monastics held roles of leadership. However, more recently, I have observed female monastic groups emerge that have been supported by male leaders. Perhaps this the final step in leveling the playing field between genders.

In conclusion, Santmat of Bihar encompasses a systematic inward path with specific landmarks for the religious experience. Even though spontaneous euphoric states or sudden experiences are seldom reported, the tradition details that Divine light and sound are the vehicles to reach the door of śanti (Divine Union). Unlike other branches of Santmat, Santmat of Bihar traces the path to the Upanișads while drawing inspiration from the Sants of the medieval times. Through his native Bihar poetic vernacular, Maharishi Mehi illustrates the stages and experiences on the path. The four-fold structure of the path guides the followers on the inward path to sannti and guards them from immorality

\footnotetext{
In his ethnographic study, (Gross [1992] 2001) seeks to understand the persistent tradition of asceticism in India. (Oman 1903, p. 275).

Ibid.

Quoted from Howard (2013, pp. 134-35).

4 In her book, Political Philosophy of Swami Vivekananda, Kalpana Mohapatra quotes Swami Vivekananda emphasizing his views of incorporating religion in all aspects of life (Mohapatra 1996, p. 48).
} 
and the allures of siddhi. Furthermore, the walls of moral conduct (e.g., vows of not lying, stealing, killing, sexual misconduct, and avoiding intoxicating substances) and Santmat's egalitarian philosophy offer a promise for a harmonious and just society. The goal is śanti not siddhi. The one who attains the experience of śanti is the Sant, proclaims Maharishi Mehi. The other objectives lead the soul astray into the deeper darkness of immorality (even though the light of popular media now shines on the defectors). However, the religious experience of divine light and sound both leads to inner śanti and shines the light of truth and justice.

Funding: This research received no external funding.

Conflicts of Interest: The author declares no conflict of interest.

\section{References}

Bhagat, M. G. 1976. Ancient Indian Asceticism. New Delhi: Motilal Banarsidass.

Bronkhorst, Johannes. 1998. Two Sources on Indian Asceticism. Delhi: Motilal Banarsidass.

DeNapoli, Antoinette. 2014a. Our own two hands create our destiny: Narrative strategies and patterns in male sadhus' stories. Contributions to Indian Sociology 48: 333-56. [CrossRef]

DeNapoli, Antoinette. 2014b. Real Sadhus Sing to God: Gender, Asceticism, and Vernacular Religion in Rajasthan. Oxford: Oxford University Press.

Dimitrova, Diana. 2007. The development of Sanatana Dharma in the twentieth century. International Journal of Dharma Studies 11: 89-98.

Eliade, Mircea. 2009. Yoga: Immortality and Freedom. Princeton: Princeton University Press.

Gold, Daniel. 1987. Clan and lineage among the Sants: Seeds, service, substance. In The Sants: Studies in a Devotional Tradition of India. Edited by Katherine Schomer and William Hewat McLeod. Berkeley: Berkeley Religious Studies Series, pp. 305-28.

Gross, Robert L. 2001. The Sadhus of India: A Study of Hindu Asceticism. Jaipur: Rawat Publications. First published 1992.

Howard, Veena. 2013. Gandhi's Ascetic Activism: Renunciation and Social Action. New York: State University of New York Press.

Juergensmeyer, Mark. 1987. The Radhasoami revival of the Sant tradition. In The Sants: Studies in a Devotional Tradition of India. Edited by Katherine Schomer and William Hewat McLeod. Berkeley: Berkeley Religious Studies Series, pp. 338-42.

Lipner, Julius. 2010. Hindus: Their Religious Beliefs and Practices, 2nd ed. New York: Routledge.

Lucia, Amanda. 2018. Guru Sex: Charisma, Proxemic Desire, and the Haptic Logics of the Guru-Disciple Relationship. Journal of the American Academy of Religion 86: 953-88. [CrossRef]

Maharishi, Santsevi. 2008. The Harmony of all Religions. p. 322. Available online: http://www. spiritualawakeningradio.com/Harmony12-ChapterSeven-santmat.pdf (accessed on 22 March 2019).

Maharshi, Mehi. 1998. Mokṣa-Darśan. The Philosophy of Liberation. Translated by Don, and Veena Howard. Santmat Society of North America: Available online: https://archive.org/details/ PhilosophyOfLiberationAManualOfSantMatMysticism/page/n19 (accessed on 21 March2019).

Mohapatra, Kalpana. 1996. Political Philosophy of Vivekananda. New Delhi: Northern Book Center.

Oman, John Campbell. 1903. The Mystics, Ascetics, and Saints of India: A Study of Sadhuism, with an Account of the Yogis, Sanyasis, Bairagis, and Other Strange Hindu Sectarians. London: T.F. Unwin.

Partridge, Christopher. 2004. New Religions: A Guide. Oxford: Oxford University Press.

Singh, Pravesh K. 2013. The Bridge between Hindu Scriptures and Santmat. Available online: https:/ / medium.com/sant-mat-meditation-and-spirituality/maharshi-mehi-the-bridge-between-hinduscriptures-and-sant-mat-by-pravesh-k-singh-2fadde15060d\#.gyw6odt6m (accessed on 14 December 2018).

Swami Vyasanand, Ji Maharaj. 2016. The Inward Journey of the Soul: Chal Hansa Nij Desh, Kindle Edition ed. Seattle: Amazon Publishing.

Turner, Victor. 1995. The Ritual Process: Structure and Anti-Structure. Piscataway: Aldine Transactions. 